\title{
A Heterometallic Three-Dimensional Metal-Organic Framework Bearing an Unprecedented One-Dimensional Branched-Chain Secondary Building Unit
}

\author{
Jing Chen ${ }^{1,+}$, Meng-Yao Chao ${ }^{1,+}$, Yan Liu ${ }^{1}$, Bo-Wei Xu ${ }^{1}$, Wen-Hua Zhang ${ }^{1, * \mathbb{D}}$ and \\ David J. Young ${ }^{2}$ (D) \\ 1 College of Chemistry, Chemical Engineering and Materials Science, Soochow University, Suzhou 215123, \\ China; chenjing120905003@163.com (J.C.); chaomy@mail.sustech.edu.cn (M.-Y.C.); \\ liuyanlllll1@163.com (Y.L.); huhulalaxu@163.com (B.-W.X.) \\ 2 College of Engineering, Information Technology \& Environment, Charles Darwin University, Darwin, \\ Northern Territory 0909, Australia; david.young@cdu.edu.au \\ * Correspondence: whzhang@suda.edu.cn; Tel.: +86-183-6262-3042 \\ + These authors contributed equally to this work.
}

Academic Editor: Marijan Gotić

Received: 3 April 2020; Accepted: 29 April 2020; Published: 7 May 2020

\begin{abstract}
A heterometallic metal-organic framework (MOF) of $\left[\mathrm{Cd}_{6} \mathrm{Ca}_{4}(\mathrm{BTB})_{6}(\mathrm{HCOO})_{2}(\mathrm{DEF})_{2}\left(\mathrm{H}_{2} \mathrm{O}\right)_{12}\right] \cdot \mathrm{DEF} \cdot x$ Sol $\left(\mathbf{1}, \mathrm{H}_{3} \mathrm{BTB}=\right.$ benzene-1,3,5-tribenzoic acid; $\mathrm{DEF}=N, N^{\prime}$-diethylformamide; $x$ Sol. $=$ undefined solvates within the pore) was prepared by solvothermal reaction of $\mathrm{Cd}\left(\mathrm{NO}_{3}\right)_{2} \cdot 4 \mathrm{H}_{2} \mathrm{O}, \mathrm{CaO}$ and $\mathrm{H}_{3} \mathrm{BTB}$ in a mixed solvent of $\mathrm{DEF} / \mathrm{H}_{2} \mathrm{O} / \mathrm{HNO}_{3}$. The compatibility of these two divalent cations from different blocks of the periodic table results in a solid-state structure consisting of an unusual combination of a discrete V-shaped heptanuclear cluster of $\left[\mathrm{Cd}_{2} \mathrm{Ca}\right]_{2} \mathrm{Ca}^{\prime}$ and an infinite one-dimensional (1D) chain of $\left[\mathrm{Cd}_{2} \mathrm{CaCa}^{\prime}\right]_{n}$ that are orthogonally linked via a corner-shared $\mathrm{Ca}^{2+}$ ion (denoted as $\left.\mathrm{Ca}^{\prime}\right)$, giving rise to an unprecedented branched-chain secondary building unit (SBU). These SBUs propagate via tridentate BTB to yield a three-dimensional (3D) structure featuring a corner-truncated $P 4_{1}$ helix in MOF 1 . This outcome highlights the unique topologies possible via the combination of carefully chosen s- and d-block metal ions with polydentate ligands.
\end{abstract}

Keywords: metal-organic framework; heterometallic cluster; heptanuclear cluster; calcium cluster; cadmium cluster; crystal structure

\section{Introduction}

Heterometallic metal-organic frameworks (MOFs) merge the traits of two or more different metal ions in one ordered array with synergistic advantages that can be applied to catalysis [1-8], gas adsorption [9-13], bioimaging [14-16], and other applications [17-21]. The heterometal can be introduced by the direct one-pot assembly of mixed metal sources and ligands [22-29], or from preformed secondary building units (SBUs) [17,18,30-36]. Post-synthetic metal coordination to the functionalized ligands [37-46] and transmetalation/incorporation of ions into the SBUs have also been reported $[3,24,42,47-50]$.

The presence of a second metal ion in the one-pot assembly may play a structure-directing role in obtaining MOF topologies inaccessible from the individual metal sources [30-34,51]. By comparison, the post-synthetic method is better for obtaining MOFs with predictable topology, and the targeted metal ion can diffuse into the pores to trigger the cation incorporation/exchange without disrupting 
the overall framework connectivity [49,52-59]. The one-pot reaction faces the risk of forming separate MOFs from dependent metal ions, whereas the post-synthesis method has the challenge of incomplete conversion, requiring repeated experiments to obtain a desirable conversion efficiency.

The one-pot assembly of heterometallic MOFs is facilitated by metal ions of similar ionic radius and charge. Mixtures of $\mathrm{Zn}^{2+}(0.070 \pm 0.007 \mathrm{~nm})$ and $\mathrm{Mg}^{2+}(0.070 \pm 0.004 \mathrm{~nm})$ or $\mathrm{Cd}^{2+}(0.0910 \pm 0.003 \mathrm{~nm})$ and $\mathrm{Ca}^{2+}(0.103 \pm 0.005 \mathrm{~nm})$ may have promising advantages in this respect [60]. However, there are only limited reports of heterometallic MOFs of these elements, presumably because of the relatively few exploitable properties of $\mathrm{Mg}^{2+}$ and $\mathrm{Ca}^{2+}$.

Incorporating s-block metal ions, such as $\mathrm{Li}^{+}, \mathrm{Na}^{+}, \mathrm{Mg}^{2+}$, and $\mathrm{Ca}^{2+}$, into MOF assemblies may impart several advantages. For example, the flexible coordination geometries of these ions and the ionic forces between the metal ions and ligands (relative to dative bonds between a typical d-block metal ion and the ligand) may permit novel framework topologies. Some of these s-block metal ions (e.g., $\mathrm{Li}^{+}$) have additional advantages of being inexpensive and relatively non-toxic [12,50,61].

In this work, we report a three-dimensional (3D) MOF of $\left[\mathrm{Cd}_{6} \mathrm{Ca}_{4}(\mathrm{BTB})_{6}(\mathrm{HCOO})_{2}(\mathrm{DEF})_{2}\left(\mathrm{H}_{2} \mathrm{O}\right)_{12}\right]$.DEF. $x$ Sol. $\quad\left(\mathbf{1}, \mathrm{H}_{3} \mathrm{BTB}=\right.$ benzene-1,3,5-tribenzoic acid; $\mathrm{DEF}=N, N^{\prime}$-diethylformamide; $x$ Sol. $=$ undefined solvates within the pore) sustained by an unprecedented one-dimensional (1D) branched SBU, which, in turn, consists of a discrete V-shaped heptanuclear cluster of $\left[\mathrm{Cd}_{2} \mathrm{Ca}_{2} \mathrm{Ca}^{\prime}\right.$ and an infinite $1 \mathrm{D}$ chain of $\left[\mathrm{Cd}_{2} \mathrm{CaCa}^{\prime}\right]_{n}$ linked via a corner-shared $\mathrm{Ca}^{2+}$ ion (denoted as $\mathrm{Ca}^{\prime}$ ). Such a complicated MOF generated via the mixed use of a $\mathrm{Cd}^{2+}$ and $\mathrm{Ca}^{2+}$ features the first case of a framework structure containing both $\mathrm{Ca}^{2+}$ and BTB ligands. In addition, the structure of MOF $\mathbf{1}$ is dramatically different from, and in fact much more delicate than, all the literature examples that are exclusively from the assembly of $\mathrm{Cd}^{2+}$ with BTB ligands [62-65].

\section{Results and Discussion}

\subsection{Synthesis and Material Characterization of MOF 1}

The motivation for introducing $\mathrm{Ca}^{2+}$ into a $\mathrm{Cd}^{2+} / \mathrm{H}_{3} \mathrm{BTB}$ assembly originated from our quest to incorporate $\mathrm{Ca}^{2+}$ into the linear $\mathrm{Cd}_{3}$-based two-dimensional (2D) MOF of $\left[\mathrm{Cd}_{3}(\mathrm{BTB})_{2}(\mathrm{DEF})_{4}\right] \cdot 2(\mathrm{DEF})_{0.5}[62,63]$, as we and others have demonstrated that the heterometallic combinations of $\mathrm{Cd} / \mathrm{Zn}, \mathrm{Cd} / \mathrm{Co}$, and $\mathrm{Zn} / \mathrm{Co}$ are readily tolerated in linear trimetallic cluster SBUs $[26,66]$. Our previous trial of the solvothermal reaction of $\mathrm{Cd}\left(\mathrm{NO}_{3}\right)_{2} \cdot 4 \mathrm{H}_{2} \mathrm{O}$ and $\mathrm{H}_{3} \mathrm{BTB}$ in a DEF/ $/ \mathrm{H}_{2} \mathrm{O} / \mathrm{HNO}_{3}$ mixed solvent with $\mathrm{CaSO}_{4}$ yielded a $3 \mathrm{D}$ anionic $\mathrm{MOF}$ of $\left[\mathrm{Et}_{2} \mathrm{NH}_{2}\right]_{2}\left[\mathrm{Cd}_{5}(\mathrm{BTB})_{4}(\mathrm{DEF})_{2}\right] \cdot 4.75 \mathrm{DEF}$ featuring a zigzag-shaped $\mathrm{Cd}_{5}$ cluster SBU [65]. The $\left[\mathrm{Et}_{2} \mathrm{NH}_{2}\right]^{+}$cations likely arose from the acid-catalyzed hydrolysis of DEF [67-70], and subsequently served as a template for the framework formation. In the present work, we employed $\mathrm{CaO}$ as a replacement of $\mathrm{CaSO}_{4}$ to consume part of the acid, and the new neutral 3D MOF 1 was thus obtained in a high yield of $87 \%$. It is interesting to note that DEF also decomposed in the present case, with the anionic part of $\mathrm{HCOO}^{-}$acting as a bridging ligand for structure propagation.

MOF 1 contains $\mathrm{Ca}^{2+}$ as a key component, is stable under aerobic conditions, and is stable and insoluble in $\mathrm{MeOH}$, EtOH, DMF, DEF, $\mathrm{CH}_{2} \mathrm{Cl}_{2}, \mathrm{CHCl}_{3}$, and $\mathrm{MeCN}$. The powder X-ray diffraction (PXRD) pattern of the bulk crystalline sample of MOF 1 agreed well with that simulated from the single-crystal diffraction data, indicating its bulk phase purity (Figure 1). The thermogravimetric analysis (TGA) of MOF 1 indicated that the framework is stable up until ca. $100{ }^{\circ} \mathrm{C}$ (Supplementary Figure S1), followed by a continuous weight loss up to ca. $650^{\circ} \mathrm{C}$. At this stage, we were not able to provide a clear compositional analysis based on the TGA result due to the large pore cavity of MOF 1 (as will be discussed below). It is also unfortunate that there was no obvious plateau found upon initial solvate loss. The thermally unstable nature of MOF 1 prevented us from studying its surface area via gas adsorption, and our preliminary experiments suggested that MOF $\mathbf{1}$ exhibits no adsorption of $\mathrm{N}_{2}$ at $77 \mathrm{~K}$ (Supplementary Figure S2), presumably due to the collapse of the 3D framework. The Fourier-transform infrared spectrum (FT-IR) of MOF 1 contained absorptions at 
$2975 \mathrm{~cm}^{-1}, 2930 \mathrm{~cm}^{-1}$, and $1652 \mathrm{~cm}^{-1}$ corresponding to the $-\mathrm{CH}_{3},-\mathrm{CH}_{2}-$, and $-\mathrm{C}=\mathrm{O}$ bonds of te DEF solvate [71,72]. In addition, peaks at $1610 \mathrm{~cm}^{-1}, 1536 \mathrm{~cm}^{-1}$, and $1397 \mathrm{~cm}^{-1}$ were assignable as the asymmetrical and symmetrical stretching vibrations of the carboxylate $[66,73]$.

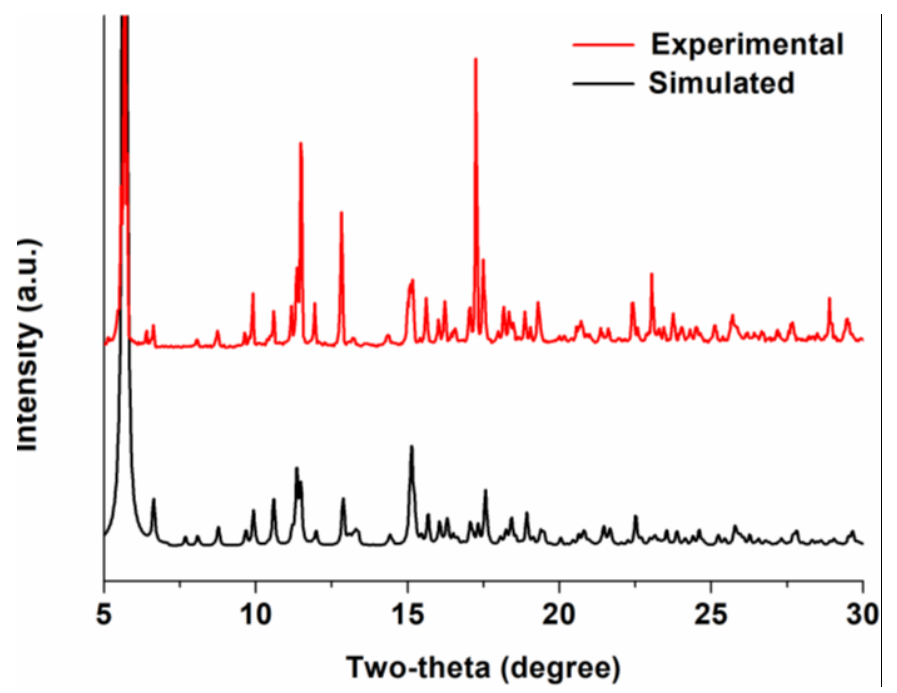

Figure 1. The powder X-ray diffraction patterns of MOF 1, showing a good consistency between the experimental (red) and simulated (black) patterns and thus a high phase purity of the bulk material. The slight inconsistency in the intensity of some peaks might have been due to the different orientation of the crystallites in the sample, as the metal-organic framework (MOF) is non-merohedrally twinned.

\subsection{Crystal Structure Analysis of MOF 1}

The presence of $\mathrm{Cd}^{2+}$ and $\mathrm{Ca}^{2+}$ and their exact atomic sites in MOF 1 could be unambiguously inferred from the X-ray crystallographic studies. This benefited from the large discrepancy of the atomic mass between $\mathrm{Cd}^{2+}(112.441)$ and $\mathrm{Ca}^{2+}(40.078)$, as any incorrect assignment of the atomic sites will lead to strikingly unrealistic thermal ellipsoids and other related issues during the structure refinement. Such MOF assemblies from a mixture of $\mathrm{Cd}^{2+}$ and $\mathrm{Ca}^{2+}$ sources thus have an advantage for structure determination by X-ray crystallography, in stark contrast to those heterometallic MOFs bearing mixed metals with similar atomic mass, such as $\mathrm{Zn} / \mathrm{Co}$ and $\mathrm{Mn} / \mathrm{Co}[23,66]$.

MOF 1 crystallizes in the tetragonal crystal system space group $I 4_{1} / a$ (Table 1 ), and its asymmetrical unit contains three $\mathrm{Cd}^{2+}$, three $\mathrm{Ca}^{2+}$, three BTB and one $\mathrm{HCOO}$ bridging ligands, together with one coordinated DEF (to $\mathrm{Cd} 3$ ) and six coordinated $\mathrm{H}_{2} \mathrm{O}$ solvates (two to $\mathrm{Cd} 1$, one to $\mathrm{Cd} 2$, one to $\mathrm{Ca} 1$, and two to Ca2). There is also one DEF solvate with half occupancy residing within the cavity of MOF 1 . As shown in Figure 2a,b, the discrete V-shaped heptanuclear $\left[\mathrm{Cd}_{2} \mathrm{Ca}\right]_{2} \mathrm{Ca}^{\prime}$ cluster contains a pair of trinuclear $\left[\mathrm{Cd}_{2} \mathrm{Ca}\right](\mathrm{Cd} 1, \mathrm{Cd} 2$ and $\mathrm{Ca} 1)$ clusters symmetrically related by one additional $\mathrm{Ca}^{\prime}$ center (Ca2) $\left(\left[\mathrm{Cd}_{2} \mathrm{Ca}\right]: \mathrm{Ca}^{\prime}=2: 1\right.$, or, alternativelym $\left.\mathrm{Cd}^{2+}: \mathrm{Ca}^{2+}=4: 3\right)$. Within the $\left[\mathrm{Cd}_{2} \mathrm{Ca}\right]$ cluster, $\mathrm{Cd} 1$ (6-coordinate) is coordinated by three distinctive carboxylates, i.e., one monodentate $\left(\eta^{1}\right)$, one bridging $\left(\mu_{2}-\eta^{1}: \eta^{1}\right)$, and one chelating-bridging $\left(\mu_{2}-\eta^{1}: \eta^{2}\right)$, in addition to two $\mathrm{H}_{2} \mathrm{O}$ solvates that terminate the propagation of the cluster. Cd2 (7-coordinate) is associated with one bridging $\left(\mu_{2}-\eta^{1}: \eta^{1}\right)$ and a pair of chelating-bridging $\left(\mu_{2}-\eta^{1}: \eta^{2}\right)$ carboxylates, one chelating-bridging HCOO $\left(\mu_{3}-\eta^{1}: \eta^{1}: \eta^{2}\right)$, and one additional coordinated $\mathrm{H}_{2} \mathrm{O}$. In addition, the central Ca1 (6-coordinate) is associated with two bridging $\left(\mu_{2}-\eta^{1}: \eta^{1}\right)$ and three chelating-bridging $\left(\mu_{2}-\eta^{1}: \eta^{2}\right)$ carboxylates, in addition to one terminally coordinated $\mathrm{H}_{2} \mathrm{O}$. On the other hand, the central $\mathrm{Ca} 2\left(\mathrm{Ca}^{\prime}, 8\right.$-connected $)$ is associated with a pair of chelating-bridging $\mathrm{HCOO}$ $\left(\mu_{3}-\eta^{1}: \eta^{1}: \eta^{2}\right)$ and four terminal $\mathrm{H}_{2} \mathrm{O}$ solvates. The $\left[\mathrm{Cd}_{2} \mathrm{Ca}\right]-\mathrm{Ca}^{\prime}-\left[\mathrm{Cd}_{2} \mathrm{Ca}\right]$ angle $(\theta)$ is roughly $132^{\circ}$ (Figure 2b). 


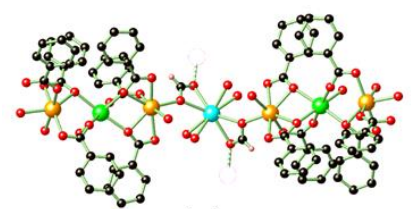

(a)

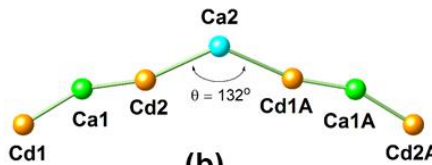

(b)

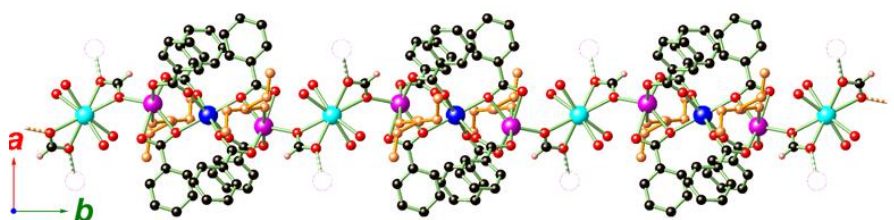

(e)

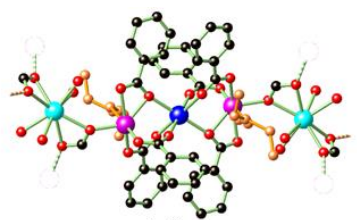

(c)

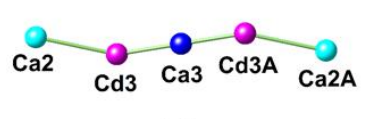

(d)

Figure 2. The structures of the discrete V-shaped heptanuclear cluster $(\mathbf{a}, \mathbf{b})$ and $1 \mathrm{D}$ rod-shaped (c-e) subunits in MOF 1, showing the full coordination geometry around each metal (a,c,e), and the framework skeleton represented by only metals $(\mathbf{b}, \mathbf{d})$. In (a), dashed bonds with blank spheres indicate that the heptanuclear cluster is orthogonally associated with the 1D rod-shaped chain via a pair of HCOO with $\mu_{3}-\eta^{1}: \eta^{1}: \eta^{2}$ coordination, and vice versa (c,e). All disordered components, dissociated DEF solvate, and hydrogen atoms (except those on $\mathrm{HCOO}$ ) are omitted for clarity. Color legend: C: black, $\mathrm{H}$ : light pink, O: red, $\mathrm{Cd} 1 / \mathrm{Cd} 2$ : orange, Cd3: magenta, Ca1: green, Ca2: cyan, Ca3: blue. The coordinated DEF solvates in (c and e) are further distinguished with orange color for clarity. Symmetrical code to generate equivalent atoms in (b): $-x,-y+1 / 2, z$, and (d): $-x,-y+1,-z+2$.

The $1 \mathrm{D}$ rod-shaped $\left[\mathrm{Cd}_{2} \mathrm{CaCa}^{\prime}\right]_{n}$ chain also contains a $\left[\mathrm{Cd}_{2} \mathrm{Ca}\right]$ cluster unit and one $\mathrm{Ca} 2\left(\mathrm{Ca}^{\prime}\right)$ center which are alternatively arranged $\left(\left[\mathrm{Cd}_{2} \mathrm{Ca}\right]: \mathrm{Ca}^{\prime}=1: 1\right.$, or, alternatively, $\left.\mathrm{Cd}^{2+}: \mathrm{Ca}^{2+}=1: 1\right)$ (Figure 2c-e). Within the chain, the Ca2 $\left(\mathrm{Ca}^{\prime}\right)$ ion is corner-shared with the V-shaped heptanuclear $\left[\mathrm{Cd}_{2} \mathrm{Ca}_{2} \mathrm{Ca}^{\prime}\right.$ cluster (Figure $2 \mathrm{a}, \mathrm{b}$ ) as discussed. The $\left[\mathrm{Cd}_{2} \mathrm{Ca}\right]$ cluster unit herein comprises a pair of $\mathrm{Cd}$ centers (Cd3) symmetrically related via the central Ca3, in which Cd3 (6-coordinate) is associated by a pair of bridging $\left(\mu_{2}-\eta^{1}: \eta^{1}\right)$ and one chelating-bridging $\left(\mu_{2}-\eta^{1}: \eta^{2}\right)$ carboxylates, one chelating-bridging HCOO $\left(\mu_{3}-\eta^{1}: \eta^{1}: \eta^{2}\right)$, and a terminally coordinated DEF solvate. Meanwhile, the central Ca3 (6-coordinate) is bonded by six carboxylates, of which four are in bridging $\left(\mu_{2}-\eta^{1}: \eta^{1}\right)$ and two in chelating-bridging $\left(\mu_{2}-\eta^{1}: \eta^{2}\right)$ coordination fashions.

The intersection of the discrete V-shaped heptanuclear $\left[\mathrm{Cd}_{2} \mathrm{Ca}\right]_{2} \mathrm{Ca}^{\prime}$ subunits and the rod-shaped $\left[\mathrm{Cd}_{2} \mathrm{CaCa}^{\prime}\right]_{\mathrm{n}}$ chain through $\mathrm{Ca}^{\prime}(\mathrm{Ca} 2)$ gives rise to a $1 \mathrm{D}$ branched SBU (Figure 3a,b). Such an unprecedentedly broad SBU features isolated voids which are filled with the bulky BTB ligands. It may be that these BTB ligands serve as the template for the arrangement of this unique SBU. These sizable SBUs are further associated with BTB ligands to give a 3D framework structure featuring densely packed BTB ligands when looking along the crystallographic $c$ direction (Figure $4 \mathrm{a}$ ). When looking along the crystallographic $a$ or $b$ direction, 1D corner-sharing channels with rhombohedral apertures are observed (Figure 4b). A Platon void calculation indicates a total solvent-accessible volume (including the free DEF) for each cell unit amounting to $22,138.0 \AA^{3}$ or $43.3 \%$ of the total cell volume $\left(51,134.0 \AA^{3}\right)$ [74]. 


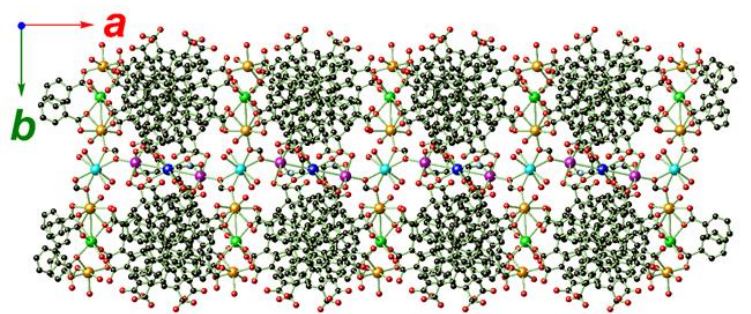

(a)

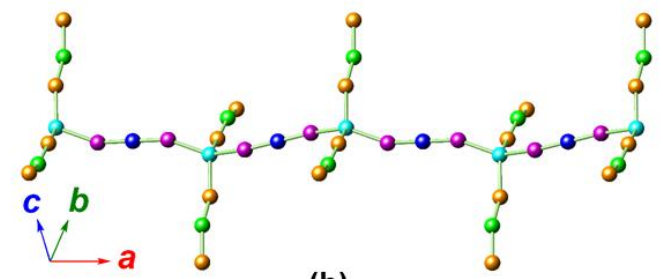

(b)

Figure 3. The 1D branched-chain SBU of MOF 1 propagated along the crystallographic $a$ direction with associated BTB ligands (a) and metal skeleton (b). All disordered components, dissociated DEF solvate, and hydrogen atoms are omitted for clarity. Color legend: C: black, O: red, Cd1/Cd2: orange, Cd3: magenta, Ca1: green, Ca2: cyan, Ca3: blue.

Table 1. Crystallographic data and refinement parameters for MOF 1.

\begin{tabular}{|c|c|}
\hline Parameter & Value \\
\hline Molecular formula & $\mathrm{C}_{179} \mathrm{H}_{141} \mathrm{Ca}_{4} \mathrm{Cd}_{6} \mathrm{~N}_{3} \mathrm{O}_{55}$ \\
\hline Formula weight & 4048.66 \\
\hline Crystal system & Tetragonal \\
\hline Space group & $I 4_{1} / a$ \\
\hline$a(\AA)$ & $30.7009(10)$ \\
\hline$b(\AA)$ & $30.7009(10)$ \\
\hline$c(\AA)$ & $54.251(4)$ \\
\hline$\alpha\left(^{\circ}\right)$ & 90 \\
\hline$\beta\left(^{\circ}\right)$ & 90 \\
\hline$\gamma\left({ }^{\circ}\right)$ & 90 \\
\hline$V\left(\AA^{3}\right)$ & $51,134(5)$ \\
\hline $\mathrm{Z}$ & 8 \\
\hline$\rho_{\text {calc }}\left(\mathrm{g} \mathrm{cm}^{-3}\right)$ & 1.052 \\
\hline$F(000)$ & 16,352 \\
\hline$\mu\left(\mathrm{mm}^{-1}\right)$ & 0.629 \\
\hline Total reflections & 438,339 \\
\hline Unique reflections & 31,735 \\
\hline Observed reflections & 28,071 \\
\hline$R_{\text {int }}$ & 0.1169 \\
\hline Variables & 1154 \\
\hline$R_{1}^{a}$ & 0.0633 \\
\hline$w R_{2}^{b}$ & 0.1615 \\
\hline $\mathrm{GOF}^{c}$ & 1.087 \\
\hline
\end{tabular}

${ }^{a} R_{1}=\Sigma|| F_{\mathrm{o}}|-| F_{\mathrm{c}} \| / \Sigma\left|F_{\mathrm{o}}\right|,{ }^{b} w R_{2}=\left\{\Sigma\left[w\left(F_{\mathrm{o}}{ }^{2}-{F_{\mathrm{c}}}^{2}\right)^{2}\right] / \Sigma\left[w\left(F_{\mathrm{o}}{ }^{2}\right)^{2}\right]\right\}^{1 / 2},{ }^{c} \mathrm{GOF}=\left\{\Sigma\left[w\left(F_{\mathrm{o}}{ }^{2}-F_{\mathrm{c}}{ }^{2}\right)^{2}\right] /(n-p)\right\}^{1 / 2}$, where $n$ is the number of reflections and $p$ is total number of parameters refined. 


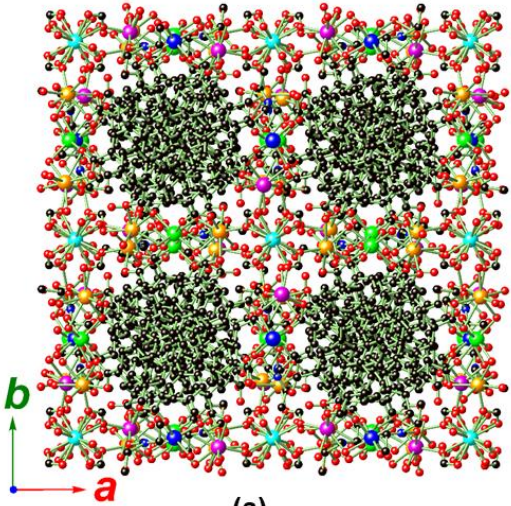

(a)

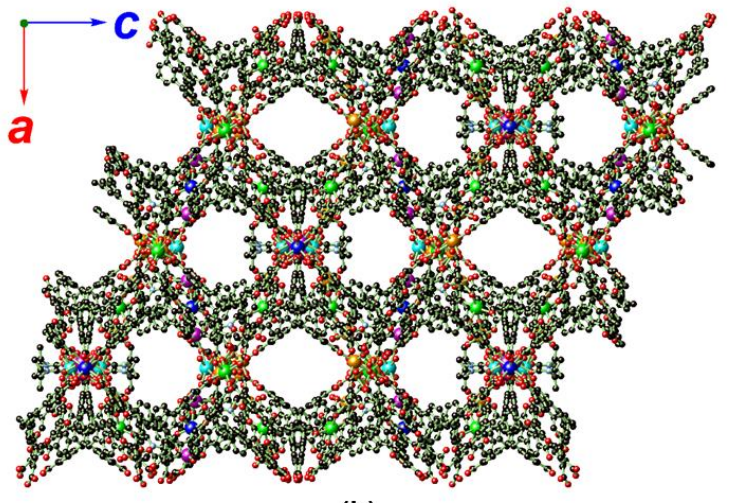

(b)

Figure 4. Crystal packing diagrams of MOF 1 looking along the crystallographic $c$ direction, showing the densely packed BTB ligands (a), and along the crystallographic $b$ direction, showing the channels with rhombohedral apertures (b). All disordered components, dissociated DEF solvate, and hydrogen atoms are omitted for clarity. Color legend: C: black, N: light blue, O: red, Cd1/Cd2: orange, Cd3: magenta, Ca1: green, Ca2: cyan, Ca3: blue.

It is interesting to note that the two types of $\left[\mathrm{Cd}_{2} \mathrm{Ca}\right]$ cluster units $(\mathrm{Cd} 1-\mathrm{Ca} 1-\mathrm{Cd} 2$ denoted as type A node, and Cd3-Ca3-Cd3 denoted as type B node; ratio type A:type B = 2:1) propagate in the $c$ direction in a helical sequence around the $4_{1}$ axis (Figure 5). In such a helical chain, the $\mathrm{Ca}^{\prime}(\mathrm{Ca} 2$, denoted as type $\mathrm{C}$ node) is critical and serves as the corner mediating the turn between type $\mathrm{A}$ and type B nodes. However, an additional corner to mediate the turn between two sequential type A nodes is missing (we herein use node $\square$ to represent such an imaginary corner). These four types of node (A, $\mathrm{B}, \mathrm{C}$, and $\square)$ are linked in a $-[\cdots \mathrm{A} \square \mathrm{ACBC} \mathrm{A} \square \mathrm{ACBC} \cdots]_{\mathrm{n}}$ - fashion with an extremely long helical pitch of 54.251(4) $\AA$ (four A $\square$ ACBC sequences, equal to the crystallographic $c$ distance) containing 44 metal ions (24 Cd and $20 \mathrm{Ca}$, respectively, Figure $5 \mathrm{~b}, \mathrm{c}$ ).

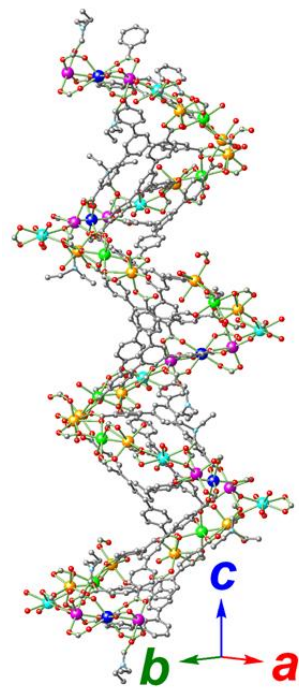

(a)

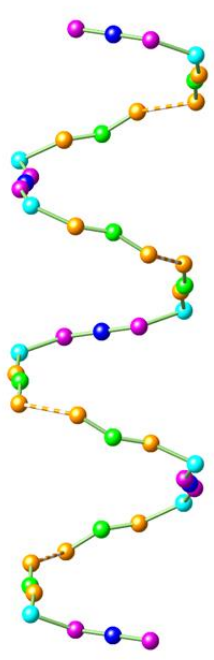

(b)

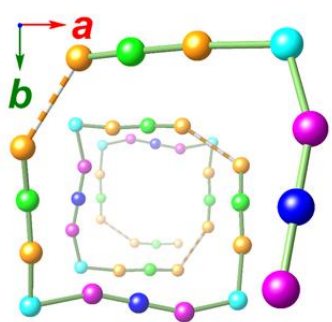

(c)

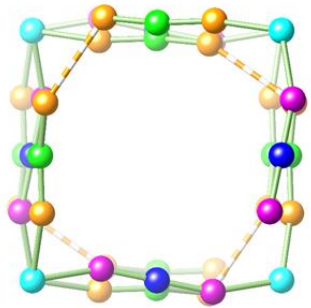

(d)

Figure 5. Structures of MOF 1 showing a helical chain propagating along the $c$ direction assisted by the BTB ligands (a), skeleton structure with only metals (b), and the perspective (c) and parallel (d) views of the helical chain along the $c$ direction. Dashed bonds are used in $(\mathbf{b}-\mathbf{d})$ to indicate imaginary connections between $\mathrm{Cd} 1$ and its equivalents to facilitate understanding of the structure. All disordered components, dissociated DEF solvate, and hydrogen atoms are omitted for clarity. Color legend: C: gray, N: light blue, O: red, Cd1/Cd2: orange, Cd3: magenta, Ca1: green, Ca2: cyan, Ca3: blue. The BTB ligand skeletons and coordinated DEF in (a) are further distinguished by gray for clarity. 
From a topological perspective, we may consider $\mathrm{Ca}^{\prime}(\mathrm{Ca} 2)$ as a tetrahedral 4-connecting node (type $\mathrm{C}$ node, presented as cyan in Figure 6) that is linked to a pair of neighboring equivalents in the crystallographic $b$ direction (within the rod-shaped chain, Figure $6 c, d$ ) and a pair of $\left[\mathrm{Cd}_{2} \mathrm{Ca}\right]$ (type A node presented as orange in Figure 6). The four angles around the $\mathrm{Ca}^{\prime}$ (Ca2) are $\theta 1=136^{\circ}, \theta 2=\theta 3=$ $99^{\circ}$, and $\theta 4=152^{\circ}$ (Figure 6b). Four type A nodes are arranged in a head-to-head fashion to generate a small $\mathrm{A}_{4}$ motif. This $\mathrm{A}_{4}$ motif also functions as a tetrahedral node and extends to four type $\mathrm{C}$ nodes, and ultimately gives rise to a diamond-type 3D network.

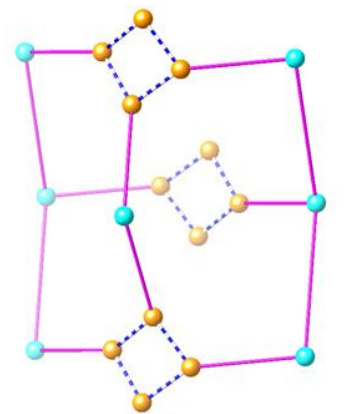

(a)

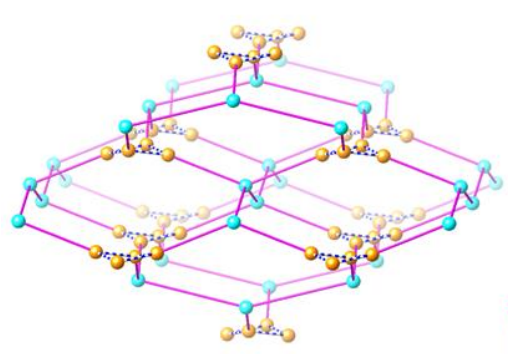

(c)

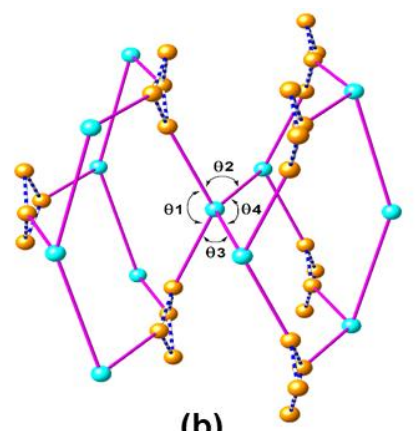

(b)

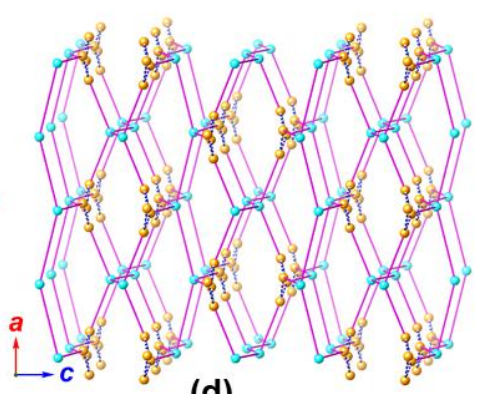

(d)

Figure 6. Topological presentations of MOF 1, with the $\left[\mathrm{Cd}_{2} \mathrm{Ca}\right]$ subunits $(\mathrm{Cd} 1-\mathrm{Ca} 1-\mathrm{Cd} 2)$ presented as orange spheres, and $\mathrm{Ca} 2$ ions that mediate the association of the V-shaped heptanuclear cluster and $1 \mathrm{D}$ rod-shaped chain presented as cyan spheres. The $\left[\mathrm{Cd}_{2} \mathrm{Ca}\right]$ subunits $(\mathrm{Cd} 3-\mathrm{Ca} 3-\mathrm{Cd} 3)$ within the $1 \mathrm{D}$ rod-shaped subunits have no topological contribution and are thus omitted. A set of four $\left[\mathrm{Cd}_{2} \mathrm{Ca}\right]$ subunits (Cd1-Ca1-Cd2) are spatially clustered and they are grouped using dashed lines to facilitate topological understanding. These subunits function either as the edge $\left(\left[\mathrm{Cd}_{2} \mathrm{Ca}\right]\right.$ cluster within the $1 \mathrm{D}$ rod-shaped chain), or the vertices (Ca2 or four $\left[\mathrm{Cd}_{2} \mathrm{Ca}\right]$ clusters of the heptanuclear subunits that collectively serve as one vertex) in a diamondoid network. Figure (a) shows a repeating unit of the diamondoid network, i.e., an adamantane unit consisting of 10 vertices, while (b) depicts two vertex-shared adamantane units. Figure $(\mathbf{c}, \mathbf{d})$ show the diamondoid network looking along the crystallographic $b$ axis, with (c) also elucidating connections among these clusters.

It should be noted that the MOF 1 structure reported herein is drastically different from, and as a matter of fact more complicated than, several BTB-based MOFs of Cd, such as 2D MOF of $\left[\mathrm{Cd}_{3}(\mathrm{BTB})_{2}(\mathrm{DEF})_{4}\right] \cdot 2(\mathrm{DEF})_{0.5}[62-64], 3 \mathrm{D} \mathrm{MOF}$ of $\left[\mathrm{Et}_{2} \mathrm{NH}_{2}\right]_{2}\left[\mathrm{Cd}_{5}(\mathrm{BTB})_{4}(\mathrm{DEF})_{2}\right] \cdot 4.75 \mathrm{DEF}$ [65], and 3D MOF of $\left[\mathrm{NEt}_{4}\right]_{2}\left[\mathrm{Cd}_{5}(\mathrm{BTB})_{4}\left(\mathrm{H}_{2} \mathrm{O}\right)_{4}\right]$ [64]. We are not aware of any BTB-based MOFs of Ca reported to date.

\section{Synthesis and Material Characterization}

\subsection{General}

$\mathrm{Cd}\left(\mathrm{NO}_{3}\right)_{2} \cdot 4 \mathrm{H}_{2} \mathrm{O}\left(\geq 99.99 \%\right.$, Macklin), benzene-1,3,5-tribenzoic acid $\left(\mathrm{H}_{3} \mathrm{BTB},>98.0 \%\right.$, $\left.\mathrm{TCI}\right)$, $N, N^{\prime}$-diethylformamide (DEF, > 99.0\%, TCI), $\mathrm{CaO}$ (98.0\%, Macklin), and $\mathrm{HNO}_{3}(65.0-68.0 \%$, Enox) were obtained from commercial sources and used as received. Fourier-transform infrared (FT-IR) 
spectrum was measured on a Varian 1000 FT-IR spectrometer (Varian, Inc., Palo Alto, CA, USA) as KBr disks (400-4000 $\mathrm{cm}^{-1}$ ). Elemental analyses for $\mathrm{C}, \mathrm{H}$, and $\mathrm{N}$ were conducted on a Carlo-Erba CHNO-S microanalyzer (Carlo Erba, Waltham, MA, USA), with the sample first immersed in $\mathrm{CHCl}_{3}$ to replace the encapsulated species with volatile $\mathrm{CHCl}_{3}$ and air-dried before analysis. The thermogravimetric analysis (TGA) was performed on a TA instrument Q500 (TA instruments, New Castle, DE, USA) from room temperature to $800^{\circ} \mathrm{C}$ at a heating rate of $10^{\circ} \mathrm{C} \mathrm{min}{ }^{-1}$ under an $\mathrm{N}_{2}$ gas flow in an $\mathrm{Al}_{2} \mathrm{O}_{3}$ pan. The powder X-ray diffraction (PXRD) pattern was recorded on a Bruker D8 GADDS (General Area Detector Diffraction System) micro-diffractometer (Bruker AXS GmbH, Karlsruhe, Germany) equipped with a VANTEC-2000 area detector (Bruker AXS GmbH, Karlsruhe, Germany) using the $\Phi$ rotation method. Nitrogen adsorption isotherms were recorded using a BELSORP-max (MicrotracBEL Corp., Osaka, Japan). The encapsulated solvent in the sample was exchanged with $\mathrm{CHCl}_{3}$ twice and air-dried in the fumehood, before being transferred to the instrument for activation at room temperature under a vacuum of $10^{-2} \mathrm{kPa}$. The evacuated sample tube was weighed again after $36 \mathrm{~h}$ and the sample mass was determined by subtracting the original mass. The nitrogen isotherms were measured using a liquid nitrogen bath $(77 \mathrm{~K})$.

\subsection{Synthesis of $\left[\mathrm{Cd}_{6} \mathrm{Ca}_{4}(\mathrm{BTB})_{6}(\mathrm{HCOO})_{2}(\mathrm{DEF})_{2}\left(\mathrm{H}_{2} \mathrm{O}\right)_{12}\right] \cdot \mathrm{DEF} \cdot x$ Sol. $(\mathrm{MOF}$ 1)}

$\mathrm{Cd}\left(\mathrm{NO}_{3}\right)_{2} \cdot 4 \mathrm{H}_{2} \mathrm{O}(31 \mathrm{mg}, 0.1 \mathrm{mmol}), \mathrm{CaO}(2.8 \mathrm{mg}, 0.05 \mathrm{mmol})$ and $\mathrm{H}_{3} \mathrm{BTB}(44 \mathrm{mg}, 0.1 \mathrm{mmol})$ were added to a mixture of $\mathrm{DEF} / \mathrm{H}_{2} \mathrm{O} / \mathrm{HNO}_{3}(6.5 \mathrm{~mL} / 1.0 \mathrm{~mL} / 50 \mu \mathrm{L})$ in a sealed pressure tube $(25 \mathrm{~mL})$. The reaction was heated to $85^{\circ} \mathrm{C}$ in an oven for $72 \mathrm{~h}$ and cooled to room temperature over $48 \mathrm{~h}$ to give colorless block crystals of $\left[\mathrm{Cd}_{6} \mathrm{Ca}_{4}(\mathrm{BTB})_{6}(\mathrm{HCOO})_{2}(\mathrm{DEF})_{2}\left(\mathrm{H}_{2} \mathrm{O}\right)_{12}\right] \cdot \mathrm{DEF} \cdot x \mathrm{Sol}$. (1). Yield $44 \mathrm{mg}$, $87 \%$ based on Ca. Anal. Calcd (\%) for $\left[\mathrm{Cd}_{6} \mathrm{Ca}_{4}(\mathrm{BTB})_{6}(\mathrm{HCOO})_{2}(\mathrm{DEF})_{2}\left(\mathrm{H}_{2} \mathrm{O}\right)_{12}\right] \cdot \mathrm{DEF} \cdot 2 \mathrm{CHCl}_{3} \cdot 8 \mathrm{H}_{2} \mathrm{O}: \mathrm{C}$ 48.97, H 3.79, N 0.95; found: C 48.71, H 4.31, N 0.96. IR (KBr disk, cm ${ }^{-1}$ ): 3416 (br), 3065 (m), 2975 (w), 2930 (m), 1937 (w), 1812 (w), 1652(s), 1610 (sh), 1582(s), 1536 (s), 1397 (vs), 1303 (m), 1265 (m), 1210 (m), $1180(\mathrm{~m}), 1146(\mathrm{w}), 1105(\mathrm{~m}), 893(\mathrm{w}), 855(\mathrm{~m}), 812(\mathrm{~m}), 780(\mathrm{~s}), 704(\mathrm{~m}), 670(\mathrm{w}), 649(\mathrm{w}), 540(\mathrm{w}), 471(\mathrm{w})$.

\subsection{X-Ray Crystallography for MOF 1}

The single-crystal structure of MOF 1 was analyzed on a Bruker D8 Quest CCD X-ray diffractometer with graphite monochromated Mo $\mathrm{K} \alpha(\lambda=0.71073 \AA)$ radiation. Refinement and reduction of the collected data were achieved using the Bruker SAINT program and applied to all complexes with absorption correction (multi-scan) [75]. The crystal structure was solved by direct methods and refined on $F^{2}$ by full-matrix least-squares techniques with the SHELXTL-2013 program [76]. In MOF 1, the two coordinated waters (O25 and O26) display positional disorder with relative ratios of 0.54/0.46 refined for the two components. The occupancy factors for the atoms of the dissociated DEF solvate were fixed at 0.5 to obtain reasonable thermal factors. The hydrogen atoms on the water molecules $(\mathrm{O} 21, \mathrm{O} 23$, and $\mathrm{O} 24)$ were located from the difference Fourier map, while those on the water molecule (O22) were generated by considering their possible hydrogen-bonding interactions with atoms nearby. The $\mathrm{O}-\mathrm{H}$ distances and thermal parameters were subsequently constrained to $\mathrm{O}-\mathrm{H}=0.83 \AA$ and $U_{\text {iso }}(\mathrm{H})=$ $1.2 U_{\mathrm{eq}}(\mathrm{O})$. The hydrogen atoms on the disordered water solvates $(\mathrm{O} 25, \mathrm{O} 26 / \mathrm{O} 25 \mathrm{a}, \mathrm{O} 26 \mathrm{a})$ were not located. The structure adopted non-merohedral twinning about the $(-1-10)$ and the twin law $[0$

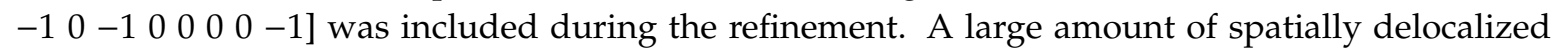
electron density in the lattice was also found (3247 electrons in 20,271 $\AA^{3}$ solvent-accessible volume), but acceptable refinement could not be obtained for this electron density. The solvent contribution was then modeled using SQUEEZE in the Platon program suite [77]. Crystallographic data were deposited with the Cambridge Crystallographic Data Center as supplementary publication number CCDC 1990807. These data can be obtained free of charge from the Cambridge Crystallographic Data Centre via www.ccdc.cam.ac.uk/data_request/cif. A summary of the key crystallographic data is listed in Table 1, and selected bond lengths and angles are depicted in Supplementary Table S1. 


\section{Conclusions}

The isolation of MOF 1 exemplified the usefulness of s-block metal ions for the MOF assembly. The three independent $\mathrm{Ca}^{2+}$ ions in MOF 1 exhibit coordination numbers of either six (Ca1 and Ca3) or eight (Ca2), with the latter seldom achieved for a typical first or second-row d-block metal complex. The structure of MOF 1 is complex and dramatically different from MOFs exclusively based on Cd-BTB. $\mathrm{Cd}^{2+}$ and $\mathrm{Ca}^{2+}$, although similar in size, are quite different in atomic mass, which made them easy to distinguish during the $\mathrm{X}$-ray crystal structure analysis. MOF $\mathbf{1}$ was insufficiently stable for complete removal of solvate from the large pore, which prevented us from obtaining meaningful porosity data via gas adsorption studies. Nevertheless, we believe that careful selection of s-block metals to mix with d-block metal ions (not limited to two) could be a powerful strategy for preparing MOFs with interesting topologies and unique properties.

Supplementary Materials: Figure S1: The TGA curve of MOF 1 showing that the framework is stable up to ca. $100{ }^{\circ} \mathrm{C}$, followed by continuous weight loss and framework decomposition until ca. $650{ }^{\circ} \mathrm{C}$; Figure S2: The $\mathrm{N}_{2}$ $(77 \mathrm{~K})$ sorption isotherms of MOF 1 with the black squares and red circles representing adsorption and desorption. $\mathrm{P}_{0}$ is the saturated vapor pressure of the adsorbates at the measurement temperatures; Table S1: Selected bond distances in MOF 1 involving the Cd and Ca centers.

Author Contributions: J.C. and M.-Y.C. conducted the experiments and drafted the manuscript; Y.L. and B.-W.X. performed the compound characterizations; W.-H.Z. conceived the idea and revised the manuscript; D.J.Y. revised the manuscript. All the authors contributed to the discussions of the project and read the manuscript. All authors have read and agreed to the published version of the manuscript.

Funding: The authors thank the financial support from the National Natural Science Foundation of China (Grant Nos. 21871203 and 21671143).

Conflicts of Interest: The authors declare no conflict of interest.

\section{References}

1. Zhu, L.; Liu, X.-Q.; Jiang, H.-L.; Sun, L.-B. Metal-organic frameworks for heterogeneous basic catalysis. Chem. Rev. 2017, 117, 8129-8176. [CrossRef] [PubMed]

2. Buchwalter, P.; Rosé, J.; Braunstein, P. Multimetallic catalysis based on heterometallic complexes and clusters. Chem. Rev. 2015, 115, 28-126. [CrossRef] [PubMed]

3. Wen, Y.; Zhang, J.; Xu, Q.; Wu, X.-T.; Zhu, Q.-L. Pore surface engineering of metal-organic frameworks for heterogeneous catalysis. Coord. Chem. Rev. 2018, 376, 248-276. [CrossRef]

4. Sun, W.; He, C.; Liu, T.; Duan, C. Synergistic catalysis for light-driven proton reduction using a polyoxometalate-based $\mathrm{Cu}-\mathrm{Ni}$ heterometallic-organic framework. Chem. Commmun. 2019, 55, 3805-3808. [CrossRef] [PubMed]

5. Liu, J.; Yang, G.-P.; Jin, J.; Wu, D.; Ma, L.-F.; Wang, Y.-Y. A first new porous d-p HMOF material with multiple active sites for excellent $\mathrm{CO}_{2}$ capture and catalysis. Chem. Commmun. 2020, 56, 2395-2398. [CrossRef] [PubMed]

6. Broere, D.L.J.; Modder, D.K.; Blokker, E.; Siegler, M.A.; van der Vlugt, J.I. Metal-metal interactions in heterobimetallic complexes with dinucleating redox-active ligands. Angew. Chem. Int. Ed. 2016, 55, 2406-2410. [CrossRef] [PubMed]

7. Hinde, C.S.; Webb, W.R.; Chew, B.K.J.; Tan, H.R.; Zhang, W.-H.; Hor, T.S.A.; Raja, R. Utilisation of gold nanoparticles on amine-functionalised $\mathrm{UiO}-66\left(\mathrm{NH}_{2}-\mathrm{UiO}-66\right)$ nanocrystals for selective tandem catalytic reactions. Chem. Commun. 2016, 52, 6557-6560. [CrossRef]

8. Nguyen, A.I.; Suess, D.L.M.; Darago, L.E.; Oyala, P.H.; Levine, D.S.; Ziegler, M.S.; Britt, R.D.; Tilley, T.D. Manganese-cobalt oxido cubanes relevant to manganese-doped water oxidation catalysts. J. Am. Chem. Soc. 2017, 139, 5579-5587. [CrossRef]

9. Botas, J.A.; Calleja, G.; Sánchez-Sánchez, M.; Orcajo, M.G. Cobalt doping of the MOF-5 framework and its effect on gas-adsorption properties. Langmuir 2010, 26, 5300-5303. [CrossRef]

10. Song, X.; Jeong, S.; Kim, D.; Lah, M.S. Transmetalations in two metal-organic frameworks with different framework flexibilities: Kinetics and core-shell heterostructure. CrystEngComm 2012, 14, 5753-5756. [CrossRef] 
11. Song, X.; Kim, T.K.; Kim, H.; Kim, D.; Jeong, S.; Moon, H.R.; Lah, M.S. Post-synthetic modifications of framework metal ions in isostructural metal-organic frameworks: Core-shell heterostructures via selective transmetalations. Chem. Mater. 2012, 24, 3065-3073. [CrossRef]

12. Zhai, Q.-G.; Bu, X.; Mao, C.; Zhao, X.; Feng, P. Systematic and dramatic tuning on gas sorption performance in heterometallic metal-organic frameworks. J. Am. Chem. Soc. 2016, 138, 2524-2527. [CrossRef] [PubMed]

13. Dincă, M.; Long, J.R. High-enthalpy hydrogen adsorption in cation-exchanged variants of the microporous metal-organic framework $\mathrm{Mn}_{3}\left[\left(\mathrm{Mn}_{4} \mathrm{Cl}\right)_{3}(\mathrm{BTT})_{8}\left(\mathrm{CH}_{3} \mathrm{OH}\right)_{10}\right]_{2}$. J. Am. Chem. Soc. 2007, 129, 11172-11176. [CrossRef] [PubMed]

14. Pandey, A.; Dhas, N.; Deshmukh, P.; Caro, C.; Patil, P.; Luisa García-Martín, M.; Padya, B.; Nikam, A.; Mehta, T.; Mutalik, S. Heterogeneous surface architectured metal-organic frameworks for cancer therapy, imaging, and biosensing: A state-of-the-art review. Coord. Chem. Rev. 2020, 409, 213212. [CrossRef]

15. Hao, C.; Wu, X.; Sun, M.; Zhang, H.; Yuan, A.; Xu, L.; Xu, C.; Kuang, H. Chiral core-shell upconversion nanoparticle@MOF nanoassemblies for quantification and bioimaging of reactive oxygen species in vivo. J. Am. Chem. Soc. 2019, 141, 19373-19378. [CrossRef]

16. Wang, H.-S. Metal-organic frameworks for biosensing and bioimaging applications. Coord. Chem. Rev. 2017, 349, 139-155. [CrossRef]

17. Zhang, W.-H.; Ren, Z.-G.; Lang, J.-P. Rational construction of functional molybdenum (tungsten)-copper-sulfur coordination oligomers and polymers from preformed cluster precursors. Chem. Soc. Rev. 2016, 45, 4995-5019. [CrossRef]

18. Liu, Q.; Zhang, W.-H.; Lang, J.-P. Versatile thiomolybdate(thiotungstate)-copper-sulfide clusters and multidimensional polymers linked by cyanides. Coord. Chem. Rev. 2017, 350, 248-274. [CrossRef]

19. Qiao, X.; Ma, Z.; Si, L.; Ding, W.; Xu, G. Doping metal-organic framework with a series of europium-antenna cations: Obviously improved spectral response for $\mathrm{O}_{2}$ gas via long-range energy roll-back procedure. Sens. Actuators B Chem. 2019, 299, 126978. [CrossRef]

20. Rybak, J.-C.; Hailmann, M.; Matthes, P.R.; Zurawski, A.; Nitsch, J.; Steffen, A.; Heck, J.G.; Feldmann, C.; Goetzendoerfer, S.; Meinhardt, J.; et al. Metal-organic framework luminescence in the yellow gap by codoping of the homoleptic imidazolate $\infty_{\infty}^{3}\left[\mathrm{Ba}(\mathrm{Im})_{2}\right]$ with divalent europium. J. Am. Chem. Soc. 2013, 135, 6896-6902. [CrossRef]

21. Zheng, F.; Yang, Y.; Chen, Q. High lithium anodic performance of highly nitrogen-doped porous carbon prepared from a metal-organic framework. Nat. Commun. 2014, 5, 5261. [CrossRef] [PubMed]

22. Sapianik, A.A.; Zorina-Tikhonova, E.N.; Kiskin, M.A.; Samsonenko, D.G.; Kovalenko, K.A.; Sidorov, A.A.; Eremenko, I.L.; Dybtsev, D.N.; Blake, A.J.; Argent, S.P.; et al. Rational synthesis and investigation of porous metal-organic framework materials from a preorganized heterometallic carboxylate building block. Inorg. Chem. 2017, 56, 1599-1608. [CrossRef] [PubMed]

23. Bauer, C.A.; Jones, S.C.; Kinnibrugh, T.L.; Tongwa, P.; Farrell, R.A.; Vakil, A.; Timofeeva, T.V.; Khrustalev, V.N.; Allendorf, M.D. Homo- and heterometallic luminescent 2D stilbene metal-organic frameworks. Dalton Trans. 2014, 43, 2925-2935. [CrossRef] [PubMed]

24. Abednatanzi, S.; Gohari Derakhshandeh, P.; Depauw, H.; Coudert, F.-X.; Vrielinck, H.; Van Der Voort, P.; Leus, K. Mixed-metal metal-organic frameworks. Chem. Soc. Rev. 2019, 48, 2535-2565. [CrossRef]

25. Castells-Gil, J.; Padial Natalia, M.; Almora-Barrios, N.; Albero, J.; Ruiz-Salvador, A.R.; González-Platas, J.; García, H.; Martí-Gastaldo, C. Chemical engineering of photoactivity in heterometallic titanium-organic frameworks by metal doping. Angew. Chem. Int. Ed. 2018, 57, 8453-8457. [CrossRef]

26. Chao, M.-Y.; Chen, J.; Young, D.J.; Zhang, W.-H.; Lang, J.-P. Smoothing the single-crystal to single-crystal conversions of a two-dimensional metal-organic framework via the hetero-metal doping of the linear trimetallic secondary building unit. Dalton. Trans. 2018, 47, 13722-13729. [CrossRef]

27. Wu, B.; Zhang, W.-H.; Lang, J.-P. Site-selective homo- and hetero-metallic doping of a 1D Zn-based coordination polymer to enhance the dimensionality and photocurrent responses. CrystEngComm 2016, 18, 3048-3054. [CrossRef]

28. Chen, C.; Wang, N.; Long, Y.; Gao, J.; Xie, W.; Ran, X.; Yue, S. Series of novel 3D microporous heterometallic $3 \mathrm{~d}-4 \mathrm{f}$ coordination frameworks with $(5,6)$-connected topology: Synthesis, crystal structure and magnetic properties. CrystEngComm 2013, 15, 4611-4616. [CrossRef] 
29. Bo, Q.-B.; Wang, H.-Y.; Wang, D.-Q.; Zhang, Z.-W.; Miao, J.-L.; Sun, G.-X. Structure and photoluminescence tuning features of $\mathrm{Mn}^{2+}$ - and $\mathrm{Ln}^{3+}$-activated $\mathrm{Zn}$-based heterometal-organic frameworks (MOFs) with a single 5-methylisophthalic acid ligand. Inorg. Chem. 2011, 50, 10163-10177. [CrossRef]

30. Schoedel, A.; Zaworotko, M.J. $\left[\mathrm{M}_{3}\left(\mu_{3}-\mathrm{O}\right)\left(\mathrm{O}_{2} \mathrm{CR}\right)_{6}\right]$ and related trigonal prisms: Versatile molecular building blocks for crystal engineering of metal-organic material platforms. Chem. Sci. 2014, 5, 1269-1282. [CrossRef]

31. Perry, J.J.I.V.; Perman, J.A.; Zaworotko, M.J. Design and synthesis of metal-organic frameworks using metal-organic polyhedra as supermolecular building blocks. Chem. Soc. Rev. 2009, 38, 1400-1417. [CrossRef] [PubMed]

32. Feng, L.; Wang, K.-Y.; Day, G.S.; Zhou, H.-C. The chemistry of multi-component and hierarchical framework compounds. Chem. Soc. Rev. 2019, 48, 4823-4853. [CrossRef] [PubMed]

33. Tu, B.; Diestel, L.; Shi, Z.-L.; Bandara, W.R.L.N.; Chen, Y.; Lin, W.; Zhang, Y.-B.; Telfer, S.G.; Li, Q. Harnessing bottom-up self-assembly to position five distinct components in an ordered porous framework. Angew. Chem. Int. Ed. 2019, 58, 5348-5353. [CrossRef] [PubMed]

34. Pang, Q.; Tu, B.; Li, Q. Metal-organic frameworks with multicomponents in order. Coord. Chem. Rev. 2019, 388, 107-125. [CrossRef]

35. Lin, Q.; Bu, X.; Kong, A.; Mao, C.; Zhao, X.; Bu, F.; Feng, P. New heterometallic zirconium metalloporphyrin frameworks and their heteroatom-activated high-surface-area carbon derivatives. J. Am. Chem. Soc. 2015, 137, 2235-2238. [CrossRef]

36. Zhang, W.-H.; Liu, Q.; Lang, J.-P. Heterometallic transition metal clusters and cluster-supported coordination polymers derived from $\mathrm{Tp}$ - and $\mathrm{Tp} \mathrm{p}^{*}$-based $\mathrm{Mo}(\mathrm{W})$ sulfido precursors. Coord. Chem. Rev. 2015, 293-294, 187-210. [CrossRef]

37. Kim, I.S.; Ahn, S.; Vermeulen, N.A.; Webber, T.E.; Gallington, L.C.; Chapman, K.W.; Penn, R.L.; Hupp, J.T.; Farha, O.K.; Notestein, J.M.; et al. The synthesis science of targeted vapor-phase metal-organic framework postmodification. J. Am. Chem. Soc. 2020, 142, 242-250. [CrossRef]

38. Zheng, J.; Ye, J.; Ortuño, M.A.; Fulton, J.L.; Gutiérrez, O.Y.; Camaioni, D.M.; Motkuri, R.K.; Li, Z.; Webber, T.E.; Mehdi, B.L.; et al. Selective methane oxidation to methanol on Cu-oxo dimers stabilized by zirconia nodes of an NU-1000 metal-organic framework. J. Am. Chem. Soc. 2019, 141, 9292-9304. [CrossRef]

39. Dunning Samuel, G.; Nandra, G.; Conn Adam, D.; Chai, W.; Sikma, R.E.; Lee Ji, S.; Kunal, P.; Reynolds Joseph, E.; Chang, J.-S.; Steiner, A.; et al. A metal-organic framework with cooperative phosphines that permit post-synthetic installation of open metal sites. Angew. Chem. Int. Ed. 2018, 57, 9295-9299. [CrossRef]

40. Huxley, M.; Coghlan, C.J.; Burgun, A.; Tarzia, A.; Sumida, K.; Sumby, C.J.; Doonan, C.J. Site-specific metal and ligand substitutions in a microporous $\mathrm{Mn}^{2+}$-based metal-organic framework. Dalton Trans. 2016, 45, 4431-4438. [CrossRef]

41. Bloch, W.M.; Burgun, A.; Doonan, C.J.; Sumby, C.J. Probing post-synthetic metallation in metal-organic frameworks: Insights from X-ray crystallography. Chem. Commun. 2015, 51, 5486-5489. [CrossRef]

42. Evans, J.D.; Sumby, C.J.; Doonan, C.J. Post-synthetic metalation of metal-organic frameworks. Chem. Soc. Rev. 2014, 43, 5933-5951. [CrossRef]

43. Blake, A.J.; Champness, N.R.; Easun, T.L.; Allan, D.R.; Nowell, H.; George, M.W.; Jia, J.; Sun, X.-Z. Photoreactivity examined through incorporation in metal-organic frameworks. Nat. Chem. 2010, 2, 688-694. [CrossRef] [PubMed]

44. Lin, S.-X.; Pan, W.-L.; Niu, R.-J.; Liu, Y.; Chen, J.-X.; Zhang, W.-H.; Lang, J.-P.; Young, D.J. Effective loading of cisplatin into a nanoscale UiO-66 metal-organic framework with preformed defects. Dalton Trans. 2019, 48, 5308-5314. [CrossRef] [PubMed]

45. Yee, K.-K.; Reimer, N.; Liu, J.; Cheng, S.-Y.; Yiu, S.-M.; Weber, J.; Stock, N.; Xu, Z. Effective mercury sorption by thiol-laced metal-organic frameworks: In strong acid and the vapor phase. J. Am. Chem. Soc. 2013, 135, 7795-7798. [CrossRef] [PubMed]

46. Hou, Y.-L.; Yee, K.-K.; Wong, Y.-L.; Zha, M.; He, J.; Zeller, M.; Hunter, A.D.; Yang, K.; Xu, Z. Metalation triggers single crystalline order in a porous solid. J. Am. Chem. Soc. 2016, 138, 14852-14855. [CrossRef]

47. Zanon, A.; Verpoort, F. Metals@ZIFs: Catalytic applications and size selective catalysis. Coord. Chem. Rev. 2017, 353, 201-222. [CrossRef]

48. Smith, S.J.D.; Ladewig, B.P.; Hill, A.J.; Lau, C.H.; Hill, M.R. Post-synthetic Ti exchanged UiO-66 metal-organic frameworks that deliver exceptional gas permeability in mixed matrix membranes. Sci. Rep. 2015, 5, 7823. [CrossRef] 
49. Lalonde, M.; Bury, W.; Karagiaridi, O.; Brown, Z.; Hupp, J.T.; Farha, O.K. Transmetalation: Routes to metal exchange within metal-organic frameworks. J. Mater. Chem. A 2013, 1, 5453-5468. [CrossRef]

50. Chen, J.-X.; Chen, M.; Ding, N.-N.; Chen, W.-H.; Zhang, W.-H.; Hor, T.S.A.; Young, D.J. Transmetalation of a dodecahedral $\mathrm{Na}_{9}$ aggregate-based polymer: A facile route to water stable $\mathrm{Cu}(\mathrm{II})$ coordination networks. Inorg. Chem. 2014, 53, 7446-7454. [CrossRef]

51. Jin, L.; Li, X.-X.; Qi, Y.-J.; Niu, P.-P.; Zheng, S.-T. Giant hollow heterometallic polyoxoniobates with sodalite-type lanthanide-tungsten-oxide cages: Discrete nanoclusters and extended frameworks. Angew. Chem. Int. Ed. 2016, 55, 13793-13797. [CrossRef] [PubMed]

52. Brozek, C.K.; Dincă, M. Cation exchange at the secondary building units of metal-organic frameworks. Chem. Soc. Rev. 2014, 43, 5456-5467. [CrossRef]

53. Albalad, J.; Arinez-Soriano, J.; Vidal-Gancedo, J.; Lloveras, V.; Juanhuix, J.; Imaz, I.; Aliaga-Alcalde, N.; Maspoch, D. Hetero-bimetallic paddlewheel clusters in coordination polymers formed by a water-induced single-crystal-to-single-crystal transformation. Chem. Commun. 2016, 52, 13397-13400. [CrossRef] [PubMed]

54. Das, S.; Kim, H.; Kim, K. Metathesis in single crystal: Complete and reversible exchange of metal ions constituting the frameworks of metal-organic frameworks. J. Am. Chem. Soc. 2009, 131, 3814-3815. [CrossRef] [PubMed]

55. Brozek, C.K.; Dincă, M. Ti ${ }^{3+}-, \mathrm{V}^{2+} \beta^{3+}-\mathrm{Cr}^{2+} \beta^{3+}, \mathrm{Mn}^{2+}-$, and $\mathrm{Fe}^{2+}$-substituted MOF-5 and redox reactivity in Cr- and Fe-MOF-5. J. Am. Chem. Soc. 2013, 135, 12886-12891. [CrossRef] [PubMed]

56. Zou, L.; Feng, D.; Liu, T.-F.; Chen, Y.-P.; Yuan, S.; Wang, K.; Wang, X.; Fordham, S.; Zhou, H.-C. A versatile synthetic route for the preparation of titanium metal-organic frameworks. Chem. Sci. 2016, 7, 1063-1069. [CrossRef]

57. Liu, T.-F.; Zou, L.; Feng, D.; Chen, Y.-P.; Fordham, S.; Wang, X.; Liu, Y.; Zhou, H.-C. Stepwise synthesis of robust metal-organic frameworks via postsynthetic metathesis and oxidation of metal nodes in a single-crystal to single-crystal transformation. J. Am. Chem. Soc. 2014, 136, 7813-7816. [CrossRef]

58. Zhu, X.-W.; Zhou, X.-P.; Li, D. Exceptionally water stable heterometallic gyroidal MOFs: Tuning the porosity and hydrophobicity by doping metal ions. Chem. Commun. 2016, 52, 6513-6516. [CrossRef]

59. Jiang, L.; Wu, N.; Li, Q.; Li, J.; Wu, D.; Li, Y. Heterometallic strategy for enhancing the dynamic separation of $\mathrm{C}_{2} \mathrm{H}_{2} / \mathrm{CO}_{2}$ : A linear pentanuclear cluster-based metal-organic framework. Inorg. Chem. 2019, 58, 4080-4084. [CrossRef]

60. Marcus, Y. Ionic radii in aqueous solutions. Chem. Rev. 1988, 88, 1475-1498. [CrossRef]

61. Banerjee, D.; Parise, J.B. Recent advances in s-block metal carboxylate networks. Cryst. Growth Des. 2011, 11, 4704-4720. [CrossRef]

62. Zhang, Z.-X.; Ding, N.-N.; Zhang, W.-H.; Chen, J.-X.; Young, D.J.; Hor, T.S.A. Stitching 2D polymeric layers into flexible interpenetrated metal-organic frameworks within single crystals. Angew. Chem. Int. Ed. 2014, 53, 4628-4632. [CrossRef] [PubMed]

63. Chao, M.-Y.; Chen, J.; Hao, Z.-M.; Tang, X.-Y.; Ding, L.; Zhang, W.-H.; Young, D.J.; Lang, J.-P. A single-crystal to single-crystal conversion scheme for a two-dimensional metal-organic framework bearing linear $\mathrm{Cd}_{3}$ secondary building units. Cryst. Growth Des. 2019, 19, 724-729. [CrossRef]

64. Xiang, H.; Gao, W.-Y.; Zhong, D.-C.; Jiang, L.; Lu, T.-B. The diverse structures of Cd(II) coordination polymers with 1,3,5-benzenetribenzoate tuned by organic bases. CrystEngComm 2011, 13, 5825-5832. [CrossRef]

65. Chao, M.-Y.; Chen, J.; Wu, X.-Y.; Wang, R.-Y.; Wang, P.-P.; Ding, L.; Young, D.J.; Zhang, W.-H. Unconventional pyridyl ligand inclusion within a flexible metal-organic framework bearing an $\mathrm{N}, \mathrm{N}^{\prime}$-diethylformamide (DEF)-solvated $\mathrm{Cd}_{5}$ cluster secondary building unit. ChemPlusChem 2020, 85, 503-509. [CrossRef] [PubMed]

66. Wang, Y.; Bredenkoetter, B.; Rieger, B.; Volkmer, D. Two-dimensional metal-organic frameworks (MOFs) constructed from heterotrinuclear coordination units and 4,4'-biphenyldicarboxylate ligands. Dalton Trans. 2007, 689-696. [CrossRef]

67. Paul, A.; Connolly, D.; Schulz, M.; Pryce, M.T.; Vos, J.G. Effect of water during the quantitation of formate in photocatalytic studies on $\mathrm{CO}_{2}$ reduction in dimethylformamide. Inorg. Chem. 2012, 51, 1977-1979. [CrossRef]

68. Burrows, A.D.; Cassar, K.; Friend, R.M.W.; Mahon, M.F.; Rigby, S.P.; Warren, J.E. Solvent hydrolysis and templating effects in the synthesis of metal-organic frameworks. CrystEngComm 2005, 7, 548-550. [CrossRef]

69. Armaghan, M.; Shang, X.J.; Yuan, Y.Q.; Young, D.J.; Zhang, W.H.; Hor, T.S.A.; Lang, J.P. Metal-organic frameworks via emissive metal-carboxylate zwitterion intermediates. ChemPlusChem 2015, 80, 1231-1234. [CrossRef] 
70. Shi, Y.-X.; Hu, F.-L.; Zhang, W.-H.; Lang, J.-P. A unique Zn(II)-based MOF fluorescent probe for the dual detection of nitroaromatics and ketones in water. CrystEngComm 2015, 17, 9404-9412. [CrossRef]

71. Mu, B.; Huang, Y.; Walton, K.S. A metal-organic framework with coordinatively unsaturated metal centers and microporous structure. CrystEngComm 2010, 12, 2347-2349. [CrossRef]

72. Chao, M.-Y.; Zhang, W.-H.; Lang, J.-P. $\mathrm{Co}_{2}$ and $\mathrm{Co}_{3}$ mixed cluster secondary building unit approach toward a three-dimensional metal-organic framework with permanent porosity. Molecules 2018, 23, 755. [CrossRef] [PubMed]

73. Yuan, F.-L.; Yuan, Y.-Q.; Chao, M.-Y.; Young, D.J.; Zhang, W.-H.; Lang, J.-P. Deciphering the structural relationships of five Cd-based metal-organic frameworks. Inorg. Chem. 2017, 56, 6522-6531. [CrossRef] [PubMed]

74. Spek, A.L. Single-crystal structure validation with the program PLATON. J. Appl. Cryst. 2003, 36, 7-13. [CrossRef]

75. Bruker. APEX2, SAINT and SADABS; Bruker ACS Inc.: Madison, WI, USA, 2014.

76. Sheldrick, G. Crystal structure refinement with SHELXL. Acta Crystallogr. Sect. C 2015, 71, 3-8. [CrossRef] [PubMed]

77. Spek, A.L. PLATON SQUEEZE: A tool for the calculation of the disordered solvent contribution to the calculated structure factors. Acta Crystallogr. Sect. C 2015, 71, 9-18. [CrossRef]

Sample Availability: Sample of MOF 1 as single crystals is available from the authors. 